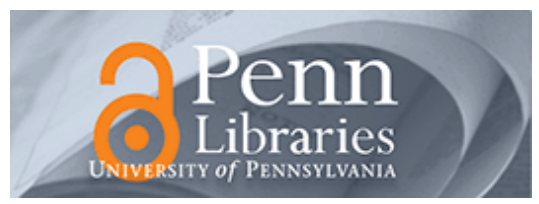

University of Pennsylvania

ScholarlyCommons

6-2015

\title{
The Tradeoff Fallacy - How Marketers Are Misrepresenting American Consumers and Opening Them up to Exploitation
}

Joseph Turow

University of Pennsylvania, jturow@asc.upenn.edu

Michael Hennessy

University of Pennsylvania, mhennessy@asc.upenn.edu

Nora A. Draper

University of Pennsylvania

Follow this and additional works at: https://repository.upenn.edu/asc_papers

Part of the Communication Commons

\section{Recommended Citation (OVERRIDE)}

Turow, J., Hennessy, M. and Draper, N. (2015). The Tradeoff Fallacy, Annenberg School for Communication.

Thanks to Penn-Annenberg doctoral students Ope Akanbi, Emily Hund, Elena Maris, Lee McGuigan, and Stephen Schrag for their help during the questionnaire-construction phase of this project. This survey was supported by The Annenberg School for Communication-Michael Delli Carpini, Dean.

This paper is posted at ScholarlyCommons. https://repository.upenn.edu/asc_papers/521

For more information, please contact repository@pobox.upenn.edu. 


\section{The Tradeoff Fallacy - How Marketers Are Misrepresenting American Consumers and Opening Them up to Exploitation}

\section{Disciplines}

Communication | Social and Behavioral Sciences

\section{Comments}

Thanks to Penn-Annenberg doctoral students Ope Akanbi, Emily Hund, Elena Maris, Lee McGuigan, and Stephen Schrag for their help during the questionnaire-construction phase of this project. This survey was supported by The Annenberg School for Communication-Michael Delli Carpini, Dean. 


\section{TIE
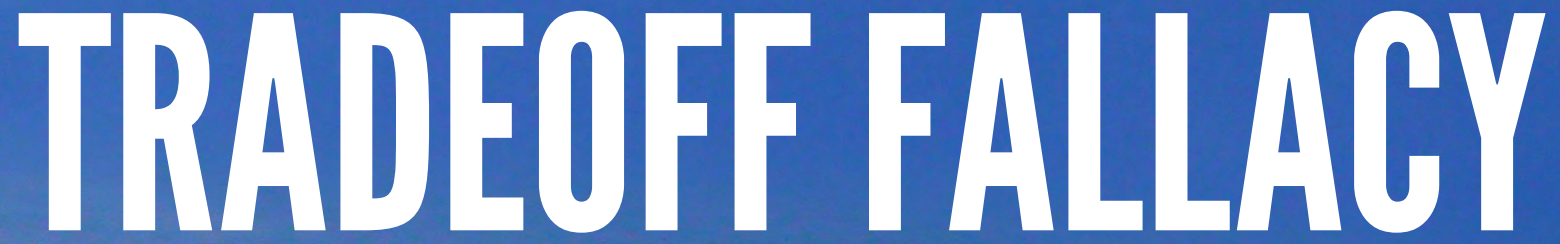

How Marketers Are Misrepresenting American Consumers And Opening Them Up to Exploitation

"Our findings... support a new explanation: a majority of Americans are resigned to giving up their data - and that is why many appear to be engaged in tradeoffs."

(See page 3)

\section{Joseph Turow Annenberg School for Communication University of Pennsylvania \\ Michael Hennessy Annenberg Public Policy Center University of Pennsylvania}

Nora Draper Department of Communication University of New Hampshire 
Joseph Turow, Ph.D., is Robert Lewis Shayon Professor of Communication at the Annenberg School for Communication, University of Pennsylvania. Among his several books are The Daily You: How the New Advertising Industry is Defining Your Identity and Your Worth (Yale University Press, 2011), Niche Envy: Marketing Discrimination in the Digital Age (MIT Press, 2006) and Breaking Up America: Advertisers and the New Media World (University of Chicago Press, 1997). Since 1999 he has conducted national telephone surveys that have moved forward public discourse on digital media, marketing, and privacy. See http://papers.ssrn.com/sol3/papers.cfm?abstract_id=2423753

Michael Hennessy, Ph.D., is project manager and statistician in the Health Communication Group of the Annenberg Public Policy Center. He has published over 120 peer-reviewed articles in journals as AIDS \& Behavior, Evaluation Review, Health Education and Behavior, Journal of Sex Research, Structural Equation Modeling, Media Psychology, Psychology Health \& Medicine, and the American Journal of Public Health. Dr. Hennessy was previously employed by the Centers for Disease Control, has held faculty positions at the University of Hawaii and Emory University, and has worked in the private sector doing evaluation research.

Nora Draper, Ph.D., is an Assistant Professor in the Department of Communication at the University of New Hampshire. Her research examines the complexities of authenticity, privacy, identity, and reputation in the digital era through frames of cultural theory, critical institutionalism, and public policy. Her work explores how identity, particularly gender, race, class, and sexuality, shape experiences of privacy, surveillance, and visibility in a digital environment. Her work has been published in the International Journal of Communication, Critical Studies in Media Communication, the Journal of Children and Media, and Surveillance \& Society.

June, 2015

Thanks to Penn-Annenberg doctoral students Ope Akanbi, Emily Hund, Elena Maris, Lee McGuigan, and Stephen Schrag for their help during the questionnaire-construction phase of this project.

This survey was supported by The Annenberg School for Communication-Michael Delli Carpini, Dean. 


\section{Overview}

New Annenberg survey results indicate that marketers are misrepresenting a large majority of Americans by claiming that Americans give out information about themselves as a tradeoff for benefits they receive. To the contrary, the survey reveals most Americans do not believe that 'data for discounts' is a square deal.

The findings also suggest, in contrast to other academics' claims, that Americans' willingness to provide personal information to marketers cannot be explained by the public's poor knowledge of the ins and outs of digital commerce. In fact, people who know more about ways marketers can use their personal information are more likely rather than less likely to accept discounts in exchange for data when presented with a real-life scenario.

Our findings, instead, support a new explanation: a majority of Americans are resigned to giving up their data - and that is why many appear to be engaging in tradeoffs. Resignation occurs when a person believes an undesirable outcome is inevitable and feels powerless to stop it. Rather than feeling able to make choices, Americans believe it is futile to manage what companies can learn about them. Our study reveals that more than half do not want to lose control over their information but also believe this loss of control has already happened.

By misrepresenting the American people and championing the tradeoff argument, marketers give policymakers false justifications for allowing the collection and use of all kinds of consumer data often in ways that the public find objectionable. Moreover, the futility we found, combined with a broad public fear about what companies can do with the data, portends serious difficulties not just for individuals but also-over time-for the institution of consumer commerce.

Marketers justify their data-collection practices with the notion of tradeoffs, depicting an informed public that understands the opportunities and costs of giving up its data and makes the positive decision to do so. A 2014 Yahoo report, for example, concluded that online Americans "demonstrate a willingness to share information, as more consumers begin to recognize the value and self-benefit of allowing advertisers to use their data in the right way." 1 This image of a powerful consumer has become a way to claim to policymakers and the media that Americans accept widespread tracking of their backgrounds, behaviors, and lifestyles across devices, even though surveys repeatedly show they object to these activities.

Our study challenges the assertion that tradeoffs explains what most Americans are doing. With the help of Princeton Survey Research Associates International, we conducted a representative national cell phone and wireline phone survey of 1,506 Americans age 18 and older who use the internet or email "at least occasionally." We presented them with everyday circumstances where marketers collect people's data, phrasing the situations as tradeoffs - and learned that very many feel those tradeoffs are unfair.

- 91\% disagree (77\% of them strongly) that "If companies give me a discount, it is a fair exchange for them to collect information about me without my knowing." 
- $71 \%$ disagree (53\% of them strongly) that "It's fair for an online or physical store to monitor what I'm doing online when I'm there, in exchange for letting me use the store's wireless internet, or Wi-Fi, without charge."

- 55\% disagree (38\% of them strongly) that "It's okay if a store where I shop uses information it has about me to create a picture of me that improves the services they provide for me.”

Further analysis of these responses indicate only a very small percentage of Americans agree with the overall concept of tradeoffs. In fact, only about $4 \%$ agree or agree strongly with all three propositions. If we use a broader definition of a belief in tradeoffs - the average value of all three statements-even then only $21 \%$ of the respondents accept the idea. Yet, when we present a real-life tradeoff caseasking Americans whether they would take discounts in exchange for allowing their supermarket to collect information about their grocery purchases - 43\%, or more than twice as many as in the broader definition of tradeoff supporters, say yes to tradeoffs." Underscoring the inconsistency, we found that $40 \%$ of the people who said they would accept the grocery-discount deal do not agree with the third tradeoff statement above even though the type of exchange it suggests is similar.

What is going on?

Contrary to the claim that a majority of Americans consent to discounts because the commercial benefits are worth the costs, our study suggests a new explanation for what has thus far been misconstrued as "tradeoff" behavior in the digital world: a large pool of Americans feel resigned to the inevitability of surveillance and the power of marketers to harvest their data. People who are resigned do not predictably decide to give up their data. We actually found no statistical relationship between being resigned to marketers' use of data and accepting or rejecting various kinds of supermarket discounts. Rather, the larger percentages of people in the population who are resigned compared to people who believe in principle that tradeoffs are a fair deal indicate that in the real world people who give up their data are more likely to do it while resigned rather than as the result of cost-benefit analysis. Marketers would have all these behaviors categorized as a rational acceptance of tradeoffs. But when we looked in our scenario at the people who agreed to give up their data for supermarket discounts, we found that $57 \%$ of those who took the deal were resigned, while even using the broader understanding of tradeoff support only $32 \%$ were "tradeoff" supporters.

To further question marketers' emphasis on Americans' use of cost-benefit calculations, we found that large percentages of Americans often don't have the basic knowledge to make informed cost-benefit choices about ways marketers use their information. Reinforcing these inaccuracies, large percentages of Americans overestimate the extent to which the government protects them from discriminatory pricing - companies changing prices from person to person based on those individuals' consumer profiles. For example:

- 49\% of American adults who use the internet believe (incorrectly) that by law a supermarket must obtain a person's permission before selling information about that person's food purchases to other companies.

- 69\% do not know that a pharmacy does not legally need a person's permission to sell information about the over-the-counter drugs that person buys.

- 65\% do not know that the statement "When a website has a privacy policy, it means the site will not share my information with other websites and companies without my permission” is false. 
- 55\% do not know it is legal for an online store to charge different people different prices at the same time of day.

- $62 \%$ do not know it is legal for an offline or physical store to charge different people different prices at the same time of day.

- 62\% do not know that price-comparison sites like Expedia or Orbitz are not legally required to include the lowest travel prices.

These misconceptions suggest that even when Americans do weigh the costs and benefits of giving up their data, they frequently base those choices on incorrect information. Ironically, and contrary to many academic claims about the reason people give up their information, those who know the most about these marketing practices are more likely to be resigned. Moreover, resigned people's decisions to accept supermarket discounts even when the supermarket collects increasingly personal information are also positively related to knowledge. When it comes to protecting their personal data, our survey finds those with the wherewithal to accurately calculate the costs and benefits of privacy are likely to consider their efforts futile.

As U.S. society moves further into the twenty-first century, personalized deals and prices will become common both online and in physical stores. These sorts of tailored offers will undoubtedly be increasingly troubling to Americans who believe they are on the losing end of often-hidden consumer profiles and targeting formulas. Suspicion already abounds: $72 \%$ of Americans reject the idea that "what companies know about me from my behavior online cannot hurt me.” It is not difficult to predict widespread social tensions, and concerns about democratic access to the marketplace, if Americans continue to be resigned to a lack of control over how, when, and what marketers learn about them. At the end of this report, we offer suggestions for turning this trend around and moving from a society where people have little hope for control over their everyday data to one in which the expectation —and reality-of control is part of transparent and responsible commercial transactions.

\section{Background}

Public opinion polls repeatedly find that consumers are concerned about ways marketers access and use their data online and offline. A 2005 national public opinion telephone survey from the University of Pennsylvania's Annenberg School found 66\% of internet-using adults did not agree "It's okay with me if supermarket I shop at keeps detailed records of my buying behavior.”2 Close to a decade later, a 2014 Pew study found $80 \%$ of social network site users in a nationally representative online poll of adult Americans answered they were concerned "that some of the information you share on social networking sites might be accessed by third parties like advertisers or businesses, without your knowledge.” ${ }^{3}$ And in 2015 the Bain \& Company consultancy reported on a survey it conducting of "more than 900 consumers" that found that "they are often uncomfortable with how their data is used and shared. A full two-thirds feel that it should be illegal for companies to collect or use such data without getting prior consent." 4

At the same time, academic and business observers concur that people often release information about themselves in ways that suggest much less concern about disclosure and collection of their personal data than the polls depict. Some have termed this gap the privacy paradox. ${ }^{5}$ It's the idea that, as reporter Brad Stone wrote in The New York Times, "normally sane people have inconsistent and contradictory 
impulses and opinions when it comes to their safeguarding their own private information." ${ }^{6}$ So, for example, a 2015 Accenture online survey found 60 percent of shoppers want real-time promotions, which often depend on sophisticated commercial surveillance. Yet, the same survey found, only 20 percent want retailers to know their location and just 14 percent are comfortable sharing their browsing history. $^{7}$

Some observers read this paradox as evidence that people don't actually care about privacy or, alternatively, that they privilege other things - convenience, discounts, social connections -above privacy. ${ }^{8}$ Marketers have embraced this seeming contradiction as a way to argue in favor of wideranging data collection. The McCann Worldwide advertising network's Truth Central project derived this conclusion from "a global research study surveying over 10,000 people in eleven countries," including the U.S. Not breaking down the results by country or detailing the survey method, McCann stated that while " $71 \%$ worry about the amount online stores know about them, $65 \%$ are willing to share their data as long as they understand the benefits for them."

The editor for mCommerceDaily interpreted the findings to mean that "the tracking of consumers all comes down to the trade-off in value.”10

Along the same lines, the president and chief strategy officer of Mobiquity, a mobile-strategy consultancy, wrote in 2012 that "the average person is more than willing to share their information with companies if these organizations see the overall gain for end-users as a goal, not just for themselves."11 A May 2014 report by Yahoo Advertising followed this logic in interpreting its survey of "6,000 respondents ages 13-64, a representative sample of the U.S. online population."12 It highlighted the finding that "Roughly two-thirds of consumers find it acceptable or are neutral to marketers using online behavior or information to craft better ads....” Digitally connected Americans, the study concluded, "demonstrate a willingness to share information, as more consumers begin to recognize the value and self-benefit of allowing advertisers to use their data in the right way."

A few corporate voices have put cautions around such generalizations. An Accenture executive said "If retailers approach and market personalization as a value exchange, and are transparent in how the data will be used, consumers will likely be more willing to engage and trade their personal data."13 Bain interpreted the results of its survey to mean that "customers' trust cannot be bought by companies offering compensation in exchange for selling or sharing personal data.” And the Brand Bond Loyalty consulting firm suggested the importance of "greater transparency of data policies and practices that are communicated clearly and concisely to consumers and [loyalty] program members."14 Yet none of these companies explained what exactly they mean by transparency; nor did they give examples of how transparency could be built into advertising systems that rely on the capture and analysis of personal information. Bain answered its clients' crucial question "how can companies acquire customer data while building customer loyalty at the same time?” by answering vaguely “Ask permission.” Brand Bond focused its report on its more central topic: emphasizing how knowledge of personal information about customers allows for personalized messages and offers which, in turn, "are likely to achieve incremental business results." These results include, it claimed, customers being three times as likely to spend more with the brand, less price-sensitive, and four times as likely “to buy something they don't want or need in order to earn points or maintain their program status.”, 15 
Like the Brand Bond report, Yahoo Advertising's underscored that "This concept of value exchange for personal data is starting to come to life through personalization." ${ }^{\text {16 }}$ In fact, for an increasing number of marketers, from finance companies to retailers, personalization is the next step in sophisticated targeting. Yahoo notes its personalization technology tracks individuals' online behaviors (their "click history") and then factors in "online activity typical of [that person's] demographic cohort."17 Statistical consultants, media-buying agencies, major advertisers, and major retail establishments have accepted this basic approach and adapted it to their needs. The common goal involves predictive analytics - the manipulation of huge amounts of data about individuals to assess the likelihood that a particular kind of content or product will lead them act in a direction desired by the marketer.

The data for these new forms of targeting can come from sources that may be obvious to the reader, viewer, or customer: registration on a site, requests for information, or perhaps the use of coupons. Increasingly, though, marketers are collecting hundreds of data points, accurate and not, about individuals in ways that are far more hidden from view. Read a typical retail chain's privacy policy, and you may well find that in the interest of personalization the merchant

- buys information from database firms to add to its data about individual customers;

- uses cookies and similar elements to follow people's behaviors on sites and in emails as well as to infer their interests across sites;

- allows advertising networks it works with to collect data about individuals coming to the site;

- tracks people's location on their mobile devices without explicit permission unless they turn that feature off;

- collects a person's comments from a product review, question, or other information on its website, app or social-network pages; and

- allows buttons from Facebook, Twitter, Pinterest, Youtube, FourSquare and other social-media sites that collect information about individuals and place trackers on their computers.

To add further to their stores of knowledge, increasing numbers of physical stores install tools that use Wi-Fi, Bluetooth Low Energy, ultrasonic and other technologies to identify individual customers' presence, track their movements, offer them personalized coupons or other messages, and link that information to everything else they know about them.

Marketers enthuse over the idea that people's acceptance of the general idea of tradeoffs justifies marketers' collection of enough data points about consumers to lead to the kind of personalization Yahoo calls "the pathway to advertising nirvana."18 Privacy advocates and researchers, by contrast, have challenged the assertion that people make rational calculations when they "opt-in" to privacyatrophying services. These groups argue that decisions about information disclosure are not as prone to contradictions between their expressed attitudes and their actions as the privacy paradox would suggest. Instead they have argued that individuals want to manage their data but lack the necessary knowledge to make informed decisions about the consequences of entering into interactions with marketers. ${ }^{19}$

From surveys, content analyses, and experiments academic researchers have argued the public is largely unable to understand what marketers are doing with their data behind the computer screen. For example, eight Annenberg School surveys from 1999 through 2012 have consistently shown that while Americans are quite aware that marketers are collecting data about them and are wary of that, they have little understanding about how that takes place or about the laws that govern those activities. ${ }^{20}$ In response, 
marketers as well as some policymakers have exhorted people to read the privacy policies to find out what particular sites and apps do with their data. Yet even some lawyers who write the policies for large companies have acknowledged to Joseph Turow that the documents are legal tender not designed to be understood by ordinary people.

Indeed, in 2012 Lorrie Faith Cranor and Aleecia McDonald determined that if internet users read every privacy policy they encountered online they would spend 25 days a year engaged in this activity. ${ }^{21}$ But before trying to read privacy policies, Americans must have a realistic reason for clicking on them. Unfortunately, Annenberg surveys have repeatedly shown that large percentages of the population consumers are misled by the very term itself. Illustrative is the finding of a 2009 Annenberg study that found 78 percent of respondents did not know the correct response -false - to the statement "If a website has a privacy policy, it means that the site cannot share information about you with other companies, unless you give the website your permission.”22 It's clear that the very term privacy policy gives people an impression of marketers' data sharing that experts agree is often quite unwarranted by the actual texts themselves.

Some critics resist the cost-benefit explanation with explanations of the public's ignorance that emphasize the difficulty of understanding the technological and institutional system. Allessandro Acquisti, Curtis Taylor, and Liad Wagman, for example, note that "new search engines, social networks, e-commerce websites, web browsers, and individualized controls for privacy-conscious consumers have emerged." 23 They conclude, however, that "While overall, these technologies seemingly leave privacy choices in the hands of consumers, many (if not most) consumers, in practice, lack the awareness and technical sophistication required to protect and regulate the multiple dimensions of their personal information." Similarly, Gordon Hull emphasizes that "users do not and cannot plausibly be expected to know enough - neither about the uses to which their information might be put, nor about the specific benefits and harms that might result from those uses, nor about the likelihood that such harms might result - for consent to be meaningful, especially if one makes the assumption that those users are following a risk/benefit model of economic rationality. 24

Note that the notion that people's lack of knowledge leaves them vulnerable to giving up their information every day to advertisers and retailers has not moved regulators in the United States to action. With the exception of certain forms of health and financial information where potential harms can be identified and quantified, and barring children under 13 years old, companies continue to be free to collect huge streams of individuals' data. They are also free to construct profiles of individuals with the data, to share the data, and to treat people differently in the marketplace based on conclusions drawn from those hidden surveillance activities. Marketers, for their part, have not been dissuaded by the knowledge-failure argument from continuing to stress the cost-benefit approach as the reason people participate in interactions that involve the disclosure of their personal information.

Both positions raise important questions for investigation. The research on how little people know about what happens behind the screen leads us to disagree that the public's acceptance of rational cost-benefit calculations explains the ease with which data retailers and advertisers retrieve information from individuals - though this proposition has never been directly tested. At the same time, we fear that the most common alternative argument - that the public allows marketers its data out of knowledge failures-gets marketers off the hook too easily. It permits them to blame schools and the media for not teaching people what they need to know about what happens behind their computer screens. It lets them 
point to online videos explaining what they do as well as to programs such as "Ad Choices" that allow people to opt out of targeted (or "interest based") advertising. And it also allows them to sound more optimistic about the public, to attribute to it more awareness and power, than those who allegedly denigrate "the value-exchange principle" marketers celebrate: "give the consumer more of what they care about and less of what they don't. It's about surfacing value for users and advertisers alike.”,25

Concerned about these drawbacks, we began to consider an alternative understanding of the "privacy paradox" that is about far more than people's cost-benefit analysis or their lack of knowledge. It is about citizens' belief they have no agency in a central area of democratic society: commerce. More than a little anecdotal evidence suggested to us that people are making conscious decisions that it is futile to even try to cope with the data tide around them. People we meet have decided they seriously cannot learn things, change government or business policy, or do anything else that will allow them to manage their personal information the way they want. Moreover, they feel that they would face significant social and economic penalties if they were to opt-out of all the services of a modern economy that rely on an exchange of content for data. They have slid into resignation-a sense that that while they want control over their data world they will never achieve it.

Frustration over lack of knowledge may have spurred this sense of resignation in many cases. Yet we have noted that even people quite knowledgeable about how the data-world works believe they have little realistic alternative to letting their data flow. They feel caught in the data-gathering marketing system for economic, social, and time-related reasons. They know they will get good prices only if they carry their supermarket's loyalty card; they believe they don't have the time, knowledge, or energy to learn how to use anonymizers; their friends are interacting on Facebook and Instagram; and they know that erasing cookies increasingly doesn't stop advertisers from tracking them, anyway. The situation echoes what Mark Andrejevic describes as the digital enclosure: the circumstance when the contemporary digital retail economy compels consumers to disclose personal information or suffer negative consequences - the slower service, limited access to discounts, and content irrelevant to their interests—-that result from opting out. ${ }^{26}$

Someone observing the behaviors of consumers might believe people are indulging in tradeoffs when they are actually resigned to giving up data. There need not be any differences between how individuals who are resigned and those who believe in tradeoffs act in marketing situations. Our goal in conducting this survey was to look behind the activities to examine people's beliefs about what they are doing and why. How broadly does a sense of resignation exist among Americans? How broadly does a belief in the appropriateness of tradeoffs exist among Americans? How does people's knowledge about everyday data gathering activities of marketers and the laws that govern them relate to their sense of resignation or belief in tradeoffs? And how do knowledge and resignation relate to people's decisions in a realistic supermarket scenario that offers discount coupons for data?

\section{The Study and Its Population}

We explored these questions as part of a survey of Americans' opinions about and understanding of a variety of online and offline privacy issues. We cast our population net broadly. We included people in our study if they were 18 years or older and said yes to one of the following questions: "Do you go online or use the internet, at least occasionally?” and “Do you send or receive email, at least 
occasionally?”

The survey questions included in this report focus on four areas. One explores Americans' attitudes regarding the fairness of three forms of marketing tradeoffs. Another explores Americans' beliefs regarding their ability to know about and exert control over the data marketers collect about them online. A third investigates people's knowledge of rules of the marketplace when it comes to sharing information in the online and offline world as well as to change prices for individuals based on location, time of day, and an individual's characteristics. A fourth explores whether Americans would respond to a specific scenario in which the supermarket they "go to most often" will give them "discounts in exchange for its collecting information about all your grocery purchases.”

The survey was conducted from February 23 to March 15, 2015 by Princeton Survey Research Associates International. PSRAI conducted telephone interviews with a nationally representative, English or Spanish speaking sample of 1,506 adult internet users living in the continental United States. A combination of landline ( $n=750)$ and wireless ( $n=756$, including 412 without a landline phone) random digit dial (RDD) samples was used to represent all adults in the continental United States who have access to either a landline or cellular telephone. The interviews averaged 20 minutes. Based on a 7callback procedure and using the American Association of Public Opinion research (AAPOR) RR3 method, a standard for this type of survey, the overall response rates were a rather typical 10 percent for the landline sample and 10 percent for the cellular sample. Statistical results are weighted to correct known demographic discrepancies. ${ }^{1}$

The margin of sampling error for the complete set of weighted data is \pm 2.9 percent at the $95 \%$ confidence level. The margin of error is higher for smaller subgroups within the sample.

Table 1 provides an introductory snapshot of the population we interviewed. As Table 1 indicates, women slightly outnumber men; 76\% designate themselves as White, 11\% identify themselves as Blacks or African American, Asians or Pacific Islanders comprise 4\%, Native Americans comprise about 1\%, and "mixed race" makes up 3\%. Hispanics (White and Black) comprise about 11\% of the sample. About 54\% are under age 45. Most have at least some higher education, and 30\% report over $\$ 75,000$ household income while $25 \%$ list it as below $\$ 30,000 ; 14 \%$ refused to reveal their household income.

\footnotetext{
${ }^{1}$ A two-stage procedure was used to weight this dual-frame sample. The first stage of weighting corrected for different probabilities of selection associated with the number of adults in each household and each respondent's telephone usage patterns. This weighting also adjusts for the overlapping landline and cell sample frames and the relative sizes of each frame and each sample.

The second stage of weighting balanced total sample demographics to population parameters. The total sample was balanced to match national population parameters for sex, age, education, race, Hispanic origin, region (U.S. Census definitions), population density, and telephone usage. The basic weighting parameters came from the U.S. Census Bureau's 2013 American Community Survey data. The population density parameter was derived from Census 2010 data. The telephone usage parameter came from the analysis of the NHIS data (Blumberg SJ, Luke JV. Wireless substitution: Early release of estimates from the National Health Interview Survey, January-June, 2014. National Center for Health Statistics. Dec 2014).
} 


\section{Consumers Reject Tradeoffs as Unfair}

To assess marketers' claim that Americans are generally positive toward allowing the collection of data about it in return for some advantage, we asked our respondents whether they agree or disagree three types of tradeoffs are "fair" or "OK." We presented the tradeoffs together with five other attitude statements in random order so as not to call attention to our particular interest in the cost-benefit

Table 1: Characteristics of U.S. Adults in Sample $(\mathrm{N}=1,506)^{*}$

\begin{tabular}{|c|c|}
\hline & $\%$ \\
\hline \multicolumn{2}{|l|}{ Sex } \\
\hline Male & 48 \\
\hline Female & 52 \\
\hline \multicolumn{2}{|l|}{ Age } \\
\hline $18-24$ & 14 \\
\hline $25-34$ & 21 \\
\hline $35-49$ & 30 \\
\hline $50-64$ & 26 \\
\hline $65-89$ & 9 \\
\hline \multicolumn{2}{|l|}{ Race } \\
\hline White & 76 \\
\hline Black or African American & 11 \\
\hline Asian or Pacific Islander & 4 \\
\hline American Indian or Alaskan Native & 2 \\
\hline Mixed Race & 3 \\
\hline Other/Don’t Know/Refused & 3 \\
\hline \multicolumn{2}{|l|}{ Hispanic or Latino Background? } \\
\hline Yes & 11 \\
\hline No & 88 \\
\hline Don’t Know/Refused & 1 \\
\hline \multicolumn{2}{|l|}{ Household Income Last Year } \\
\hline Under $\$ 30,000$ & 25 \\
\hline$\$ 30,000$ to under $\$ 50,000$ & 19 \\
\hline$\$ 50,000$ to under $\$ 75,000$ & 12 \\
\hline$\$ 75,000$ and Over & 30 \\
\hline Don’t Know/Refused & 14 \\
\hline \multicolumn{2}{|l|}{ Highest Education Level } \\
\hline Less than high school graduate & 7 \\
\hline High school/tech school graduate & 25 \\
\hline Some college & 33 \\
\hline College graduate or more & 34 \\
\hline No answer & 1 \\
\hline
\end{tabular}

* In this and all other tables, when the numbers don't add to $100 \%$ it is because of a rounding error. 
calculations. Listed in Table 2, each of the tradeoff propositions depicts an everyday data-collection approach as well as a common privilege (discount, improved service or use of a store's wireless internet) marketers claim to present in return. Note that despite these activities happening all around them, large majorities of Americans believe each form of exchange is not acceptable. Moreover, as Table 2 indicates, their rejection is firm: by far the largest majority of naysayers say they "disagree strongly."

Table 2: Americans' Responses to Tradeoff-Attitude Statements $(\mathrm{N}=\mathbf{1 , 5 0 6 )}$

\begin{tabular}{|c|c|c|c|c|c|}
\hline & $\begin{array}{l}\text { Strongly } \\
\text { Agree } \\
(\%)\end{array}$ & $\begin{array}{c}\text { Agree } \\
(\%)\end{array}$ & $\begin{array}{c}\text { Disagree } \\
(\%)\end{array}$ & $\begin{array}{l}\text { Strongly } \\
\text { Disagree } \\
(\%)\end{array}$ & $\begin{array}{c}\text { Neither* } \\
\text { (\%) }\end{array}$ \\
\hline $\begin{array}{l}\text { If companies give me a discount, it is a fair } \\
\text { exchange for them to collect information about } \\
\text { me without my knowing it. (91\% disagree) }\end{array}$ & 3 & 5 & 14 & 77 & 1 \\
\hline $\begin{array}{l}\text { It's fair for an online of physical store to monitor } \\
\text { what I'm doing online when I'm there, in } \\
\text { exchange for letting me use the store's wireless } \\
\text { internet, or Wi-Fi, without charge. ( } \mathbf{7 1 \%} \\
\text { disagree) }\end{array}$ & 9 & 18 & 18 & 53 & 2 \\
\hline $\begin{array}{l}\text { It's OK if a store where I shop uses information it } \\
\text { has about me to create a picture of me that } \\
\text { improves the services they provide for me. ( } 55 \% \\
\text { disagree) }\end{array}$ & 12 & 30 & 17 & 38 & 3 \\
\hline
\end{tabular}

*Neither was a volunteered answer.

Further analysis of these responses indicates only a very small percentage of Americans totally agree with the overall concept of marketing tradeoffs: about $4 \%$ agree or agree strongly with all three propositions. To allow for a broader interpretation of a belief in tradeoffs we created a tradeoffacceptance index that gave a value to each answer -5 to strongly agree, 4 to agree, 3 to neither agree nor disagree, 2 to disagree and 1 to strongly disagree. We then calculated the average scores respondents had on the three statements to see how many averaged disagreement or agreement with the statements. We found that even using from this broader measure a small proportion-21\% - believes common tradeoffs with marketers amount to a fair deal-in contrast to what marketers posit as the major reason for people giving up their data.

\section{The Supermarket Scenario and Cost-Benefit Analysis}

We then evaluated a form of the privacy paradox. After a block of attitude questions unrelated to tradeoffs, we presented our respondents with a more concrete data-exchange situation than the ones we used in the tradeoff-attitude statements. "For the next few questions," the interviewer said, "please think about the supermarket you go to most often. Let's say this supermarket says it will give you discounts in exchange for its collecting information about all your grocery purchases. Would you accept the offer or not?” 
A majority, 52\%, say they will not, but $43 \%$ reply they will accept supermarket scenario, and $4 \%$ volunteer "it depends"-more than twice as many as in even the broad definition of tradeoff supporters. On the surface, the percentage accepting is quite similar to the $45 \%$ who agree with the third statement in Table 2. Further analysis, though, indicates the overlap of individuals is far from complete: $40 \%$ of those who accept the supermarket discount do not concur that "It's OK if a store where I shop uses information it has about me to create a picture of me that improves the services they provide for me." This lack of correspondence even when the scenarios appear similar underscores that a small percentage consistently accept the idea of tradeoffs.

We wanted to know whether people who say they will accept the supermarket discount would still do it when presented with specific assumptions a supermarket might make about them from analyzing their grocery-purchasing habits. This is knowledge Americans almost never receive directly but may intuit in real life as a result of ads and coupons they believe are targeted to them. The categories the interviewers presented ran the gamut from generalizations that focus directly on buying habits ("whether you tend to buy low-fat foods”) to lifestyle inferences (for example, "when you take vacations”) to demographic inferences ("your racial or ethnic background") to medical generalizations ("the health status of you or someone in your family"). For each one, the interviewers asked whether respondents would accept the general discount offer under the new specific condition.

Table 3 presents their answers. It shows the limits of cost-benefit analysis (and the privacy paradox) as a rationale for marketers' claim that most people will provide personal data in exchange for store deals. There is a substantial drop in the percentage of people who say they will accept the discount when confronted with what the supermarket will infer about them. Moreover, we find that the categories make up an ordered difficulty index indicating sensitivity: individuals who say they won't exchange data for a certain trade-off topic (for example, “when you take vacations”) also won't exchange data for the topics below it in the index. ${ }^{2}$

Clearly, the percentage of Americans who seem even on the surface to accept a cost-benefit analysis does not exceed $43 \%$. And when we ask people directly to think about the implications of what they provide to marketers, they balk, and the acceptance level goes down to around $20 \%$. This decline is not consistent with marketers' assertions that people are giving up their personal information because of cost-benefit analysis. In the supermarket scenarios, they are doing just the opposite: resisting the idea of giving data for discounts.

\section{Most Americans are resigned and they far outnumber tradeoff supporters}

Here is where we begin to explore an alternative view, our resignation hypothesis. The meaning of resignation we intend is, to quote a Google dictionary entry, "the acceptance of something undesirable but inevitable.”27 Asking our respondents whether they agree or disagree with two statements, we investigated how much of the population can be described as resigned when it comes to marketers

\footnotetext{
${ }^{2}$ Using these data combined with those $52 \%$ who said they would not accept any kind of supermarket discount we created a supermarket-tradeoff index measure which goes from 0 if a person said they would not accept any supermarket discount to 9 if a respondent said they would accept a supermarket discount and also accepted all specific discounts based on shopping and demographic characteristics listed in Table 3. Note that nine percent of the respondents had the highest possible value of this index.
} 
learning about their behavior online. One statement was "I want to have control over what marketers can learn about me online." The other was "I've come to accept that I have little control over what marketers can learn about me.” We presented these statements in random order among a series of six agree/disagree propositions so that the respondents wouldn't see the relationship between the two or suspect our intention. To be identified as resigned, a person had to agree with both of them.

Table 3: Percentage of people who accept the supermarket offer and know supermarket will analyze grocery their purchases to make particular assumptions about them$\mathrm{N}=1506$

\begin{tabular}{lc}
\hline \hline & $\begin{array}{c}\text { Yes } \\
(\%)\end{array}$ \\
\hline Accept the discounts without any specific assumptions added & 43 \\
\hline Accept the discount knowing supermarket will make & \\
assumptions about & 33 \\
\hline Whether you tend to buy low-fat foods & 27 \\
Whether you have children and how old they are & 25 \\
What activities you might do outside of work & 22 \\
When you take vacations & 21 \\
The health status of you or someone in your family & 21 \\
How much money you make & 19 \\
Whether you are going through a major life event & 19 \\
Your racial or ethnic background &
\end{tabular}

Table 4 presents their answers to the statements. The percentage of people agreeing with the first one (84\%) is higher than the second, where agreement is nevertheless quite high (65\%). When we investigated the overlap that designates resignation, we found that a majority of the population-58\%is resigned. We also found widespread suspicion based on another statement we gave them: $72 \%$ of Americans reject the idea that "what companies know about me from my behavior online cannot hurt me." If we combine the people who are resigned with those who believe what firms know can hurt them, we find that $41 \%$ of Americans are not only resigned, they hold a dark concern that the basic dynamics of the emerging marketplace will cause them injury-and that they cannot control it.

Table 4: Americans’ Responses to the Resignation Attitude Statements (N=1,506)

\begin{tabular}{|c|c|c|c|c|c|c|}
\hline & $\begin{array}{l}\text { Strongly } \\
\text { Agree } \\
(\%)\end{array}$ & $\begin{array}{c}\text { Agree } \\
(\%)\end{array}$ & $\begin{array}{c}\text { Disagree } \\
\text { (\%) }\end{array}$ & $\begin{array}{l}\text { Strongly } \\
\text { Disagree } \\
(\%) \\
\end{array}$ & $\begin{array}{c}\text { Neither* } \\
(\%)\end{array}$ & $\begin{array}{l}\text { DK } \\
(\%)\end{array}$ \\
\hline $\begin{array}{l}\text { I want to have control over what } \\
\text { marketers can learn about me } \\
\text { online. ( } \mathbf{8 4 \%} \text { agree) }\end{array}$ & 61 & 23 & 8 & 7 & 1 & 1 \\
\hline $\begin{array}{l}\text { I've come to accept that I have little } \\
\text { control over what marketers can } \\
\text { learn about me online. (65\% } \\
\text { agree) }\end{array}$ & 31 & 34 & 16 & 18 & 1 & 1 \\
\hline
\end{tabular}


In the abstract, behaviors driven by cost-benefit analyses and those driven by resignation may look the same. When we looked in our scenario at the people who agreed to give up their data for supermarket discounts, we found important differences between tradeoff supporters and people who are resigned. There is a strong positive statistical relationship (.56) between the tradeoff index (based on the three statements in Table 2) and accepting or rejecting various kinds of supermarket discounts. By contrast, there is no statistical relationship (-.01) between being resigned to marketers' use of data and accepting or rejecting various kinds of supermarket discounts. Put another way, people who believe in tradeoffs give up their data predictably, while people who are resigned don't do it in a predictable manner. They do give up their data, though. In fact, we found that $57 \%$ of those who took the supermarket deal were resigned. By contrast, a much smaller 32\% were "tradeoff" supporters even using the broader measure of tradeoff support.

The larger percentages of people in the population who are resigned compared to people who believe in tradeoffs indicate that in the real world people who exchange their data for benefits are more likely to do it while resigned rather than as the result of cost-benefit analysis. Moreover, resignation is widespread across the U.S. population. As Figure 1 indicates, age and gender show no differences in resignation. When it comes to education and race, statistically significant differences do show up: higher resignation percentages for Whites compared to non-Whites and for the more educated people compared with respondents who have a high school education or less. At the same time, those comparison show that $50 \%$ or more of the individuals in most categories of respondents are resigned.

Figure 1: Percentage of Resigned Respondents by Demographic Groups

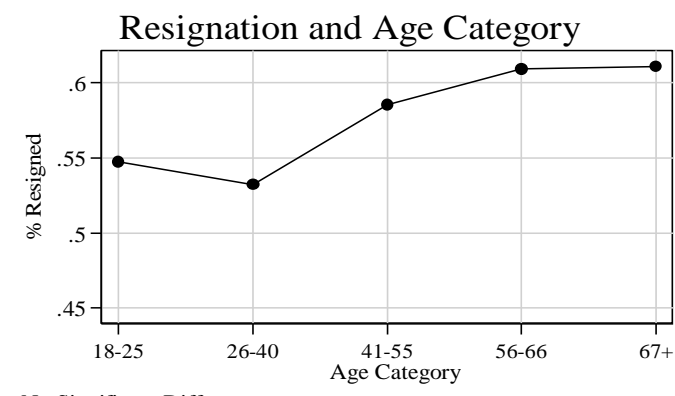

No Significant Difference

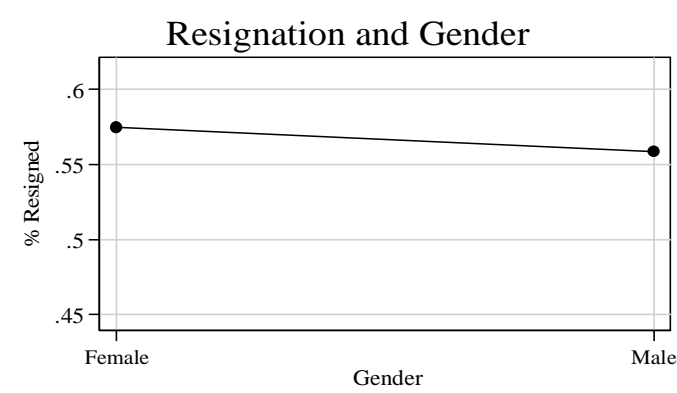

No Significant Difference
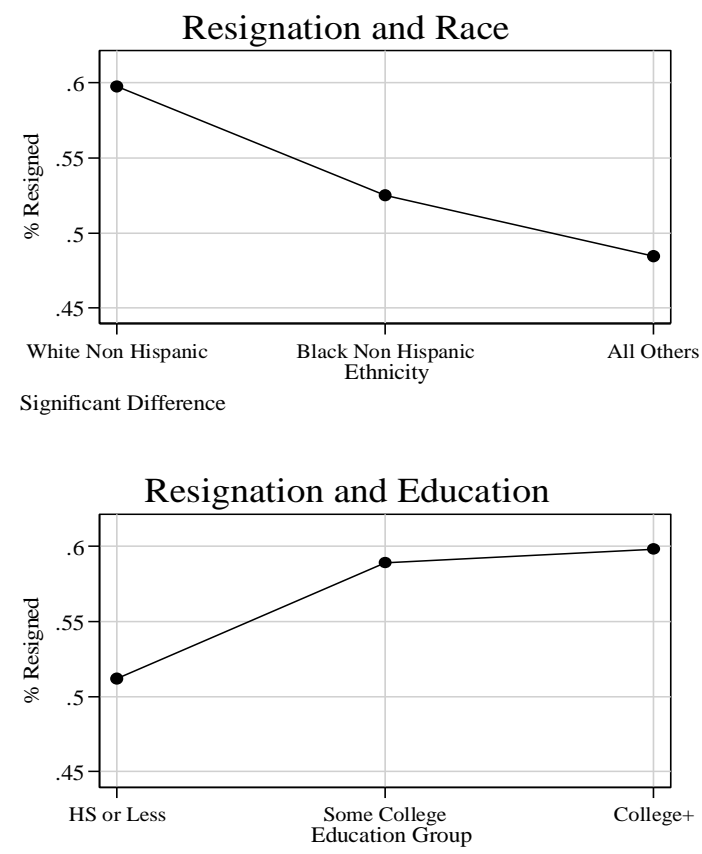

Significant Difference 


\section{Americans often don't have the basic knowledge to make informed cost-benefit choices}

To further question marketers' emphasis that Americans use cost-benefit calculations, we found that large percentages of Americans often don't have the basic knowledge to make informed cost-benefit choices about ways marketers use their information. Reinforcing these inaccuracies, large percentages of Americans overestimate the extent to which the government protects them from discriminatory pricing - the act of changing prices from person to person based on those individuals' consumer profiles. Table 5 presents the answers our respondents gave to 13 statements about how marketers use their information and the regulations relating to personalized pricing. For each statement, we asked the person "whether you think it is true or false. If you are unsure, just say so." The bolded number

Table 5: True-False statements about how marketers use information and regulations related to personalized pricing $(\mathrm{N}=1,506)$

\begin{tabular}{|c|c|c|c|c|}
\hline & $\begin{array}{l}\text { True } \\
(\%)\end{array}$ & $\begin{array}{c}\text { False } \\
(\%)\end{array}$ & $\begin{array}{l}\mathrm{DK} \\
(\%)\end{array}$ & $\begin{array}{c}\text { Wrong } \\
(\%)\end{array}$ \\
\hline $\begin{array}{l}\text { It is possible for Facebook to link what people do when they } \\
\text { access the internet on a laptop computer with what they } \\
\text { do on their cell phones' or tablets' apps. }\end{array}$ & 74 & 12 & 14 & 26 \\
\hline $\begin{array}{l}\text { It is legal for an online store to charge people different prices } \\
\text { depending on where they are located. }\end{array}$ & 63 & 26 & 10 & 36 \\
\hline $\begin{array}{l}\text { When I allow a mobile app to know my location, that app is } \\
\text { legally allowed to share that location with another } \\
\text { company. }\end{array}$ & 62 & 26 & 12 & 38 \\
\hline $\begin{array}{l}\text { A company can tell that I have opened its email even if I } \\
\text { don't respond. }\end{array}$ & 61 & 27 & 13 & 40 \\
\hline $\begin{array}{l}\text { By law, stores that provide free wireless internet, or Wi-Fi, } \\
\text { have to secure the service so nobody can track what } \\
\text { customers who are using it are doing online. }\end{array}$ & 29 & 59 & 11 & 40 \\
\hline $\begin{array}{l}\text { By law, my supermarket must obtain my permission first } \\
\text { before selling information about my food purchases to } \\
\text { other companies. }\end{array}$ & 38 & 51 & 11 & 49 \\
\hline $\begin{array}{l}\text { Banks often send their customers emails that ask them to } \\
\text { click on a link wanting them to verify their account. }\end{array}$ & 43 & 49 & 8 & 51 \\
\hline $\begin{array}{l}\text { By law, a travel site such as Expedia or Orbitz that compares } \\
\text { prices on different airlines must include the lowest airline } \\
\text { prices. }\end{array}$ & 38 & 47 & 15 & 53 \\
\hline $\begin{array}{l}\text { It is legal for an ONLINE store to charge different people } \\
\text { different prices at the same time of day. }\end{array}$ & 44 & 42 & 13 & 55 \\
\hline $\begin{array}{l}\text { When a website has a privacy policy, it means the site will } \\
\text { not share my information with other websites or } \\
\text { companies without my permission. }\end{array}$ & 38 & 50 & 12 & 62 \\
\hline $\begin{array}{l}\text { If I want to be sure not to be tracked on my cell phone, I } \\
\text { should clear the phone’s cookies. } \\
\text { By law, my pharmacy must obtain my permission first before } \\
\text { selling information about the over-the-counter drugs I } \\
\text { buy to other companies. }\end{array}$ & 46 & 35 & 18 & 64 \\
\hline
\end{tabular}


indicates the percentage that got the correct answer; the last column indicates the percentage who didn't get the answer correct (that is, the percent wrong plus the percentage who don't know or are unsure).

The table reveals a range of difficulty, with 5 statements where $40 \%$ or less didn't know the correct answer and 8 answers where from $49 \%$ to $69 \%$ didn't know the correct answer. A separate analysis revealed that half of the population got only six or fewer answers correct, while $32 \%$ got seven to nine questions right, and $17 \%$ were correct on ten to thirteen of the statements. Only $3 \%$ excelled at knowing all but two of the statements.

Overall, the table indicates large gaps in knowledge about basic data-marketing rules among large percentages of Americans. In addition to legal activities Americans cannot evaluate correctly, $51 \%$ of Americans cannot recognize the possibility of "phishing," an illegal activity where thieves posing as banks or other organizations with important data ask customers "to click on a link wanting them to verify their account.” Moreover, large percentages of the population believe incorrectly that government laws protect them from price discrimination and certain forms of data collection.

These widespread misconceptions suggest that even when Americans do weigh the costs and benefits of giving up their data, they frequently base those choices on incorrect information.

\section{More knowledge predicts being resigned and giving up data in the supermarket scenario}

While the low knowledge level of Americans about how marketers use their information makes it unlikely they could carry out correct costs-benefit calculations in the digital-marketing environment, having more knowledge is not the protective feature that academics have suggested. We found that those who know more about the marketing laws and practices are more likely to be resigned. Moreover, resigned people's decisions to accept supermarket discounts even when the supermarket collects increasingly personal information is also positively related to knowledge.

To demonstrate, we use our knowledge index based on the 13 items presented in Table 5. ${ }^{3}$ When we explore how being resigned is associated with the knowledge index, we get a plot with a significant positive slope, shown in Figure 2. The plot shows that the more a person knows about information collection in the marketing world, the more likely the resignation. In this context, knowledge definitely does not go along with a sense of power. To the contrary, our survey finds that when it comes to protecting their personal data, those with the wherewithal to accurately calculate the costs and benefits of privacy are likely to consider their efforts futile.

Resignation and increasing knowledge also work together when it comes to consumers' exchanging their grocery-buying data for discounts in the supermarket scenario. Figure 3 plots that interaction based on multiple regression analysis predicting the supermarket trade-off index (the number of data topics a person is willing to exchange) controlling for age, race, and gender. It shows that the likelihood of a person giving more data, and more sensitive data (because it is an ordered-difficulty index), goes up more sharply with increasing knowledge when the person is not resigned. The figure does indicate,

\footnotetext{
${ }^{3}$ For this analysis, we combined the respondents who got all the questions correct (a score of 13) with those who got 12 correct because the number of respondents with all correct was quite low $(\mathrm{N}=9)$.
} 
though, that resignation associates with more rather than less knowledge when it comes to predicting that a person will choose to exchange data for supermarket discounts.

Figure 2: Resignation and Knowledge ( $\mathrm{N}=1,506$; brackets define $95 \%$ confidence intervals)

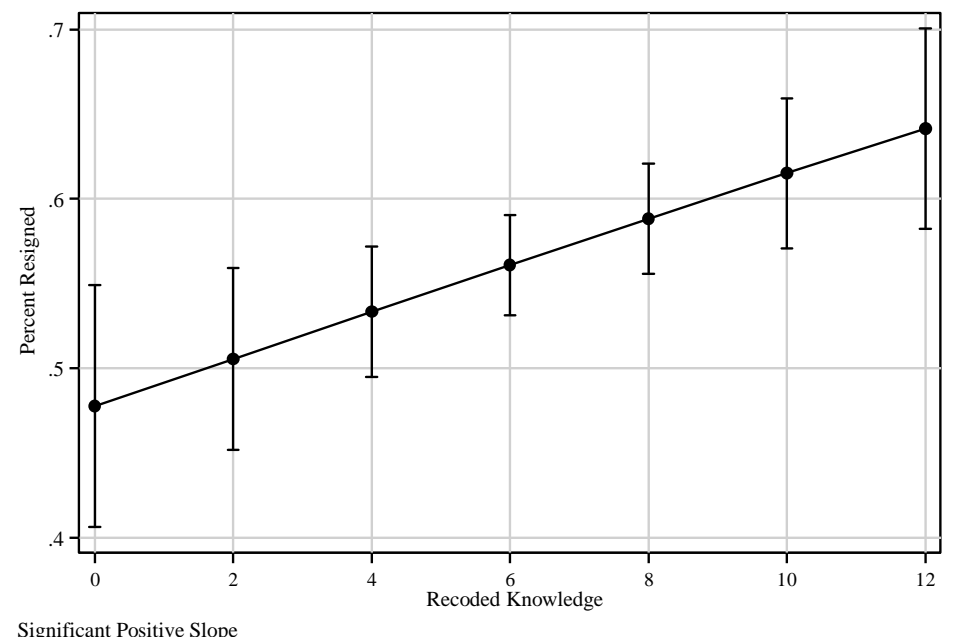

Figure 3: Interaction Plot of Knowledge and Resignation Predicting Supermarket Tradeoff Index $(\mathrm{N}=1, \mathbf{4 1 6})$

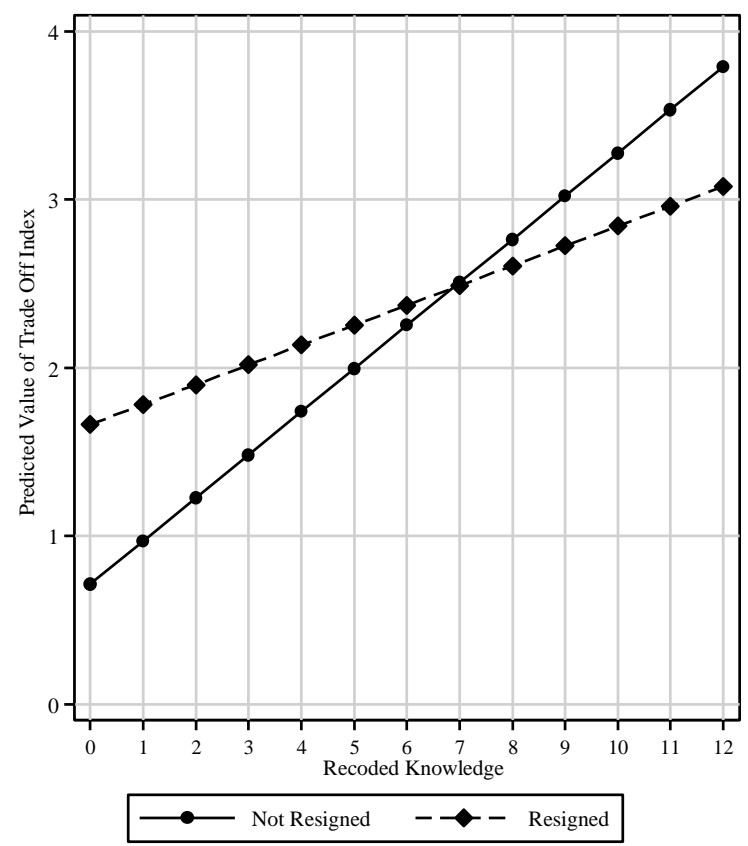

Adjusted for age, race, and gender

Significant Interaction 


\section{Concluding Remarks}

Our hope is that the results from our nationally representative survey of Americans will encourage new perspectives on the problems swirling around consumer marketers' relationships with the public. One issue raised by the findings is that Americans' are resigned regarding their ability to control the information marketers can collect and use about them. Resigned individuals may behave in ways that allow marketers to claim they are unconcerned or accept the economic logic that insists people trade their data for benefits. We found instead that most Americans reject this logic. They also express concerns about how their data are being used and don't believe marketers give them input into it. A consequence of this broad sense of futility, perhaps even disrespect, is that over the next decades Americans might reject the legitimacy of a central institution: marketing and consumer commerce. This will have a destabilizing ripple effect on many aspects of American life.

The futility over information control we are seeing in the public sphere is disrupting a compact that commercial marketers made with Americans through the past century. As historian William Leach notes, a key development of the past one hundred and fifty years was the "democratization of desire." It involved the reimagining of democracy beyond politics to Americans' "equal rights to desire the same goods" and have access to them in a shared public marketplace. ${ }^{28}$ Leach and others note that the democratization of desire had some not-so-attractive aspects; moreover, the ideal never fully took hold. Nevertheless, the growth of posted prices (as opposed to haggling in response to prices that vary by individuals or groups) and the open presentation of goods (as opposed to different goods offered to different people based on merchants' preconceived conceptions of them) are two features of the standardized marketplace that have leveled opportunities for shoppers.

One underappreciated consequence of marketers' 21st century data activities is that these and related features of the democratized marketplace are beginning to disappear. With the rise of personalization as a strategy, advertisers and retailers are changing prices for individuals (often through targeted discounts) when they shop at home, at work, and even in physical aisles, based on what the sellers know about them. Advertisers and retailers are also changing the goods they highlight for people based on the profiles they have created about them from their own and other online and offline information sources. Although some online firms have been allowing Americans to see some of the data points they hold about them, the particulars of how and when they use these profiles — and with what other sources of information - is a mystery in almost all cases. It is evident that the amount of information marketers have already collected is enormous. For example, the Forrester Research consultancy estimated in 2014 that database marketing firm Acxiom has about 1,500 data points for each of over 500 million active internet users, most of them in the United States. ${ }^{29}$ Another 2014 Forrester report looked to not-toodistant circumstances where marketers would routinely make decisions based on "a customer's circle of social relationships and influencers...sensor data [from in-store technologies], streaming real-time data, acquired data [from firms such as Acxiom]...anything.”30

Americans surely sense the changes that are happening and feel powerless to do anything about them. Our finding that 58\% of Americans are resigned to not having a say in these activities - that they do not want to lose control over their information but also believe their loss of control has already happenedsuggests the population feels a lack of autonomy even at this early date in the shift away from a democratized marketplace. We also found widespread suspicion: 72\% of Americans reject the idea that 
"what companies know about me from my behavior online cannot hurt me." When we combined the people who are resigned with those who believe what firms know can hurt them, we found that $41 \%$ of Americans are not only resigned, they hold a dark concern that the basic dynamics of the emerging marketplace will cause them injury_and that they cannot control it.

Marketing and retailing executives have typically played down any concerns about their use of shopper data. One way has been to depict an empowered public that accepts the notion that it is releasing data willingly as a tradeoff for benefits it receives. Our survey challenges marketers' typical cost-benefitanalysis defense by showing quite clearly that most Americans do not accept the fairness of getting discounts in trade for their data. But as controversies around data mining and predictive analytics have swirled around the National Security Agency as well as around tracking by businesses to ferret out people with particular diseases, financial issues, or sexual orientations, marketers have taken pains to separate out tracking people for the purposes of ordinary advertising and shopping. Consider the comments of Scott Howe, President and CEO of Acxiom:

Some believe that all data is of equal importance and therefore must be controlled in exactly the same way. This is just not the case. Data regarding personal information that pertains to employment or insurability decisions, or that relates to sensitive health-related issues or confidential matters, deserves much different treatment than data that would indicate that I am a sports fan. Too often, legislation and regulation seek to paint issues in broad strokes, often with unforeseen consequences to liberties and innovation, despite being born of the best intentions. ${ }^{31}$

Apart from ignoring the issue of information respect- that Americans want to be able to manage their data in commerce - this view pushes aside the discriminatory potential that seemingly benign pieces of data can have on the opportunities people can have in the public sphere. In the not-too-distant future, companies may well merge the category "sports fan" with dozens of other characteristics about an individuals' eating habits (at the ballpark, for example), income, number and age of children, house value, vacation habits, mobile-tracked locations, clothes-shopping habits, and media-use patterns to create profiles that dub them winners or losers regarding certain areas of shopping and the advertisements related to them. For reasons they don't understand, people may see patterns of discounts that suggest they are being siloed into certain lifestyle segments. Certain advertisers may support their media habits but not, perhaps, to the extent that advertisers support neighbors or co-workers. The individuals will vaguely understand that their profiles are the cause, and they may try to change their behavior to get better deals, often without success, all the while wondering why "the system" — the opaque under-the-hood predictive analytics regimes that they know are tracking their lives but to which they have no access-is treating them that way.

Arguments that play down the profound discriminatory potential of this sort of data-driven consumer commerce have the same rhetorical aims as arguments that insist Americans' want to exchange data for benefits: They give policymakers false justifications for enabling the collection and use of all kinds of consumer data often in ways that the public find objectionable. Yet when 3 of every 5 Americans are resigned to lack of control over their data relationships with marketers, when 2 of every 5 are both resigned to marketer control over their data and worried that the control can hurt them, and when people with knowledge are actually more likely rather than less likely to be resigned, we have a problem. The findings indicate substantial tensions in a central area of society's public sphere that cannot be swept away by executives' assertions of consumer autonomy and rational choice. 
Unfortunately, the social and institutional harms we have identified here don't map easily onto the concept of harms used by the Federal Trade Commission and other government organizations. As the FTC itself noted in a 2010 report, approaches to protecting consumer privacy that employ a harm-based model tend to focus on enhancing physical security, limiting economic injury, and minimizing unwanted intrusions into the daily lives of consumers. ${ }^{32}$ The report goes on to note that such an approach tends to leave out reputational harm and the pervasive fear many Americans face of being watched-issues that certainly intersect with concerns we have found in this survey. Yet the concerns we have identified are both more specific and broader: Americans want to have control over the data marketers use about them. They believe that marketers keep that data control for themselves. They worry (perhaps because of that lack of autonomy) that the commercial relationships they have are dangerous. And they feel resigned to not being able to do anything about it.

At heart here is an asymmetrical relationship between what marketers know about Americans and whether Americans can learn what that information is and how it's being used. The term transparency is used a lot in the marketing trade press to signify advertisers' insistence that they must be able to look into the specifics of their programmatic-advertising activities so that they can calculate their return on investment and not get harmed monetarily. Yet when it comes to transparency in advertisers' relationships with the public, the term is far less popular - and the activities related to implementing openness far less diligent. We need initiatives that will give members of the public the right and ability to learn what companies know about them, how they profile them, and what data lead to what personalized offers. We also need to get people excited about using that right and ability. Here are a few suggestions:

- One way to encourage more corporate openness about the commercial use of people's data may be by naming, praising, and shaming. Public interest organizations as well as government agencies should develop clear definitions of transparency that reflect concerns identified in this survey and elsewhere. They should then systematically call out companies regarding how well or badly they are doing based on these values. When activists, journalists, and government officials name, praise, and shame firms that don't abide by the transparency norms, they can alert the public to stay away from bad actors and possibly force those actors to change their behaviors.

- We also suggest an initiative to dissect and report on the implications of privacy policies. Activists, journalists and government officials - perhaps aided by crowdsourcing initiativesshould take on the role of interpreting these legally-binding documents for the public. The focus should not primarily be on whether or not websites abide by their privacy policies. Instead, privacy-policy interpreters can be most helpful by uncovering for their publics how companies say they collect and use their data, and what the implications might be for the individual and society. When this information is available in a digestible form, it may spur informed naming, praising, and shaming. It may well also lead firms to change behaviors citizens find disagreeable.

- These considerations along with our overall survey findings suggest a need to advocate for the right to know one's profile and how it is used. As long as the algorithms companies implement to analyze and predict the future behaviors of individuals are hidden from public view, the potential for unwanted marketer exploitation of individuals' data remains high. We therefore ought to consider it an individual's right to access the profiles and scores companies use to create every 
personalized message and discount the individual receives. Companies will push back that giving out this information will expose trade secrets. We argue there are ways to carry this out while keeping their trade secrets intact.

Without access to this information, individuals will continue to feel disempowered and disrespected by companies. Moreover, the very institution of consumer commerce may be threatened in ways that damage the broad canvas of American life.

\section{References}

${ }^{1}$ Yahoo! Advertising, The Balancing Act: Getting Personalization Right (Yahoo!, May 2014), p. 11, https://advertising.yahoo.com/Insights/BALANCING-ACT.html , accessed May 8, 2015.

${ }^{2}$ Joseph Turow, Lauren Feldman, and Kimberly Meltzer, Open to Exploitation: American Shoppers Online and Offline (University of Pennsylvania: Annenberg Public Policy Cener, 2005).

${ }^{3}$ Mary Madden, “Few feel that the government or advertisers can be trusted,” Pew Internet Project, November 12, 2014, topline questionnaire: "http://www.pewinternet.org/files/2014/11/PrivacyPanelTopline.pdf

4 "How Can Companies Acquire Customer Data While Building Customer Loyalty At The Same Time? Ask Permission," Bain \& Company, Press Release, May 11, 2015, http://www.bain.com/about/press/press-releases/Digital-privacy-survey2015-press-release.aspx

${ }^{5}$ See, for example, Sonja Utz and Nicole Kramer, "The Privacy Paradox On Social Network Sites Revisited," Cyberpsychology, 3(2) article 1, http://cyberpsychology.eu/view.php?cisloclanku=2009111001\%26article=1 , accessed April 26, 2015; and Susan B. Barnes, A privacy paradox: Social networking in the United States. First Monday, 11, http://firstmonday.org/htbin/cgiwrap/bin/ojs , accessed May 8, 2015.

${ }^{6}$ Brad Stone, “Our Paradoxical Attitudes toward Privacy,” New York Times, July 2, 2008, sec. Bits Blog, http://bits.blogs.nytimes.com/2008/07/02/our-paradoxical-attitudes-towards-privacy/.

${ }^{7}$ Jacqueline Renfrow, “Increased Spending on Loyalty Programs Not Increasing Engagement,” FierceRetail, March 27, 2915, http:/www.fierceretail.com/story/increased-spending-loyaltyprograms-not-increasing-engagement/2015-03-27.

${ }^{8}$ Gordon Hull, "Successful Failure: What Foucault Can Teach Us about Privacy Self-Management in a World of Facebook and Big Data,” December 2, 2014, http://ssrn.com/abstract=2533057.

9 “The Truth About Shopping,” McCann Truth Central, August 20, 2014, http://truthcentral.mccann.com/wpcontent/uploads/2014/09/McCann_Truth_About_Shopping_Guide.pdf , accessed May 8, 2015.

${ }^{10}$ Chuck Martin, "What The Shopper Gets Out Of Being Tracked,” mCommerceDaily, May 28, 2014, http://www.mediapost.com/publications/article/226734/what-the-shopper-gets-out-of-being-traked.html , accessed May 8, 2015

${ }^{11}$ Scott Snyder, “Mobile Devices: Facing the ‘Privacy Vs. Benefit’ Trade-Off,” Forbes.com, August 3, 2012, http://www.forbes.com/sites/ciocentral/2012/08/03/mobile-devices-facing-the-privacy-vs-benefit-trade-off/, accessed May 8, 2015.

${ }^{12}$ Yahoo! Advertising, The Balancing Act: Getting Personalization Right (Yahoo!, May 2014), p. 11, https://advertising.yahoo.com/Insights/BALANCING-ACT.html , accessed May 8, 2015. 
13 "US consumers want more personalized retail experience and control over personal information, Accenture survey shows," Accenture, March 9, 2015, http://newsroom.accenture.com/news/us-consumers-want-more-personalized-retailexperience-and-contol-over-personal-information-accenture-survey-shows.htm , accessed April 26, 2015

14 “The Loyalty Report 2014 From Bond Brand Loyalty,” Bond Brand Loyalty, 2014, http://cdn2.hubspot.net/hub/352767/file-942578460pdf/Whitepapers/Bond_Brand_Loyalty_2014_Loyalty_Report_US.pdf?t=1430494118043 , p. 21, accessed May 1, 2015.

15 “The Loyalty Report 2014 From Bond Brand Loyalty,” Bond Brand Loyalty, 2014, http://cdn2.hubspot.net/hub/352767/file-942578460pdf/Whitepapers/Bond_Brand_Loyalty_2014_Loyalty_Report_US.pdf?t=1430494118043 , p. 19, accessed May 1, 2015.

${ }^{16}$ Yahoo! Advertising, The Balancing Act: Getting Personalization Right (Yahoo!, May 2014), 7, https://advertising.yahoo.com/Insights/BALANCING-ACT.html , accessed May 8, 2015.

${ }^{17}$ Yahoo! Advertising, The Balancing Act: Getting Personalization Right (Yahoo!, May 2014), p. 2, https://advertising.yahoo.com/Insights/BALANCING-ACT.html , accessed May 8, 2015.

${ }^{18}$ Yahoo! Advertising, The Balancing Act: Getting Personalization Right (Yahoo!, May 2014), p. 2, https://advertising.yahoo.com/Insights/BALANCING-ACT.html , accessed May 8, 2015.

${ }^{19}$ See, for example, Chris Hoofnagle’s argument against the "rational choice” theory of the late privacy law expert Alan Westin: Chris Jay Hoofnagle and Jennifer M. Urban, Alan Westin's Privacy Homo Economicus, 49 Wake Forest L. Rev. 261 (2014), available at: http://scholarship.law.berkeley.edu/facpubs/2395.

${ }^{20}$ Joseph Turow, et. al., “Americans, Marketers, And The Internet: 1999-2012,” Report from the Annenberg School For Communication, University of Pennsylvania, March 2014, SSRN,

${ }^{21}$ Alicia M. McDonald and Lori F. Cranor, “The Cost of Reading Privacy Policies,” I/S: A Journal of Law and Policy for the Information Society 4, no. 3 (2008). The Federal Trade Commission has suggested it recognizes the difficulty of reading privacy policies. For example, in clarifying the "collection limitation" principle of its privacy framework, the Commission staff wrote any data collection that is inconsistent with these contexts, companies should make appropriate disclosures to consumers at a relevant time and in a prominent manner - outside of a privacy policy or other legal document.” See Federal Trade Commission, "Protecting Consumer Privacy in an Era of Rapid Change: Recommendations for Businesses and Policymakers,” Washington DC, Federal Trade Commission, March 2012, p.27.

${ }^{22}$ Joseph Turow Jennifer King, Chris Jay Hoofnagle, Amy Bleakley, and Michael Hennessy, Contrary to What Marketers Say Americans Reject Tailored Advertising and Three Activities That Enable It, Online, (September 29, 2009), 21, SSRN.

${ }^{23}$ Alessandro Acquisti, Curtis Taylor, and Liad Wagman, “ The Economics of Privacy,” Manuscript, May 2015, http://lwagman.org/Privacy_Survey.pdf , accessed May 10, 2015

${ }^{24}$ Hull, "Successful Failure: What Foucault Can Teach Us about Privacy Self-Management in a World of Facebook and Big Data," 9.

${ }^{25}$ Yahoo! Advertising, The Balancing Act: Getting Personalization Right (Yahoo!, May 2014), p. 2, https://advertising.yahoo.com/Insights/BALANCING-ACT.html , accessed May 8, 2015.

${ }^{26}$ Mark Andrejavic, I Spy: Surveillance and Power in the Interactive Era (Lawrence, Kansas: University Press of Kansas, 2007). A related concept is what Shoshana Zuboff terms "the Big Other": corporate mechanisms of information control that "effectively exile persons from their own behavior while producing new markets of behavioral prediction and modification.” See Shoshana Zuboff, "Big Other: Surveillance Capitalism And The Prospect Of An Information Civilization,: Journal Of Information Technology 2015 (30), pp. 75-89.

${ }^{27}$ Google definition of resignation, https://www.google.com/?gws rd=ssl\#q=resignation , accessed May 18, 2015.

${ }^{28}$ William Leach, Land of Desire: Merchants, Power, and the Rise of a New American Culture (New York: Vintage books, 1993), p. 6.

${ }^{29}$ Richard Joyce, “The Future of Digital Media Buying,” Forrester Research, December 2, 2014, p. 10. 
${ }^{30}$ Randy Heffner, “A Radical Rethink of Data Architecture for Customer Engagement,” Forrester Research, July 17, 2014, p. 3.

${ }^{31}$ Scott Howe, “A Price Call-to-Action for the Data Industry,” Advertising Age, April 8, 2014, http://adage.com/article/privacy-and-regulation/a-privacy-call-action-data-industry/292464/ , accessed May 18, 2015.

${ }^{32}$ Federal Trade Commission. Protecting Consumer Privacy in an Era of Rapid Change. (FTC, December 2010). https://www.ftc.gov/sites/default/files/documents/reports/federal-trade-commission-bureau-consumer-protectionpreliminary-ftc-staff-report-protecting-consumer/101201privacyreport.pdf , accessed, May 16, 2015. 